\title{
A PROTEOMIC PERSPECTIVE OF QUERCUS SUBER SOMATIC EMBRYOGENESIS
}

Aranzazu Gómez-Garay ${ }^{1}$, Juan Antonio López², , Emilio Camafeita², Mª Ángeles Bueno $^{3}$ and Beatriz Pintos ${ }^{1}$

${ }^{1}$ Departamento de Biología Vegetal I. Facultad de CC Biológicas. UCM. Madrid, Spain.

${ }^{2}$ Unidad de Proteómica, Centro Nacional de Investigaciones Cardiovasculares, CNIC. Madrid, Spain.

${ }^{3}$ INIA-CIFOR. Madrid, Spain.

${ }^{*}$ Corresponding Author:

\author{
Dra. Arancha Gómez Garay \\ Biología Vegetal I: Fisiología Vegetal \\ Facultad de CC Biológicas \\ UCM Madrid \\ Spain \\ Phone: + 34913944506 \\ Fax: + 34913889135 \\ E-mail: magom02@bio.ucm.es
}

Keywords: Quercus, somatic embryogenesis, proteomics, DIGE, MALDI, Mass spectrometry. 


\section{ABBREVIATIONS}

AA: Ascorbic acid

AFR: Ascorbate free radical

AKR: Aldo keto reductase

CAD: Cinnamyl alcohol dehydrogenase

CSE: Cotyledonar Somatic Embryos

DHA: Dehydroascorbate (synonym: dehydroascorbic acid)

GAPDH: Glyceraldehyde-3-phosphate dehydrogenase

Hsp: Heat shock protein

LEA: late embryogenesis abundant

MSE: Mature Somatic embryos

MTHP: 5-methyltetrahydropteroyltriglutamate--homocysteine methyltransferase

PCA: Principal components analysis

PR protein: Pathogenesis-related protein

PSE: Proliferating Somatic Embryos

PTM: Post-Translational Modification

ROS: Reactive Oxygen Species

SOD: superoxide dismutase 


\section{SUMMARY}

Quercus suber $\mathrm{L}$. is a forest tree with remarkable ecological, social and economic value in the southern Europe ecosystems. To circumvent the difficulties of breeding such long-lived species like $Q$. suber in a conventional fashion, clonal propagation of Q. suber elite trees can be carried out, although this process is sometimes unsuccessful. To help decipher the complex program underlying the development of Q. suber somatic embryos from the first early stage up to reaching the mature stage, a proteomic approach based on DIGE and MALDI-MS has been envisaged. Results highlighted several key processes involved in the three developmental stages (proliferative, cotyledonary and mature) of $Q$. suber somatic embryogenesis studied. Results shown that the proliferation stage is characterized by fermentation as an alternative energy source at the first steps of somatic embryo development, as well as by up-regulation of proteins involved in cell division. In this stage reactive oxygen species play a role in proliferation, while other proteins like CAD and PR5 seem to be implied in embryonic competence. In the transition to the cotyledonary stage diverse ROS detoxification enzymes are activated and reserve products (mainly carbohydrates and proteins) are accumulated, whereas energy production is increased probably to participate in the synthesis of primary metabolites such as amino acids and fatty acids. Finally, in the mature stage ethylene accumulation regulates embryo development. 


\section{INTRODUCTION}

Conventional breeding of woody plants usually involves many generations, and in the case of such long-lived forest species like cork-oak (Quercus suber L.) this breeding might become unattainable. In addition, since cork-oak lacks conventional vegetative propagation capabilities the development of in vitro propagation systems through somatic embryogenesis is highly desirable [1].

Somatic embryo development is a complex of sequential processes from the early embryo after embryogenesis induction to mature embryo attainment. Early stages are characterized by cell division and proliferation directed to establishment and development of embryo structures. To reach mature embryos, mechanisms are required to control the balance between cell division, cell expansion and cell adhesion. Several studies have attempted to ascertain the key changes that take place along the diverse stages of somatic embryo development by investigating either specific biological processes [2,3], the effects of changing embryo culture conditions on global gene expression $[4,5]$, or alterations in the proteome [e.g. 6, 7, 8]. Proteomics tools are particularly suitable for the analysis of signalling and developmental processes in plants, and have been successfully used to help unravel the embryo developmental process [see review 9]. In particular, DIGE has been used to quantitatively assess the differential expression patterns between somatic and gametic in vitro derived embryos of $Q$. suber [10]. In this work the proteins found differentially expressed were involved in a variety of cellular processes, most of which had neither been previously associated with embryo development nor identified in the genus Quercus. 
Nevertheless, somatic embryogenesis is a process characterized by repetitive embryogenesis where a cycle is initiated whereby somatic embryos proliferate from the previously existing somatic embryo in order to produce clones. However, conversion of somatic embryos into plants remains inefficient and limits the application of somatic embryogenesis in many systems. This low conversion rate is in part dependent of the quality of the somatic embryos obtained, and therefore the potential quality and viability of the somatic embryo-derived seedlings are critical. Based on the idea that high quality somatic embryos must resemble inasmuch as possible zygotic embryos several researches have focused on zygotic-somatic embryo comparisons through proteomic analysis [e.g. 11]. The objective of this work was to ascertain key regulatory processes involved in several developmental stages of $Q$. suber somatic embryogenesis by identifying the corresponding changes in protein abundance.

\section{MATERIALS AND METHODS}

\section{Somatic embryogenesis}

Somatic embryogenesis has been obtained in cork-oak from immature zygotic embryos [12]. Open pollinated acorns were taken during the period of fruit development. The basal culture medium comprises macronutrients of Sommer et al. [13] and micronutrients of Murashige and Skoog [14], with the following additions: ascorbic acid (11.3 mM), nicotinic acid (8.1 mM), glutamine (3.4 mM), calcium pantothenate $(4.2 \mathrm{mM})$, pyridoxine- $\mathrm{HCl}(4.9 \mathrm{mM})$ and thiamine- $\mathrm{HCl}(3 \mathrm{mM})$. Sucrose (88mM) was used as carbon source, and 2,4-dichlorophenoxyacetic acid was used as a growth regulator. The $\mathrm{pH}$ of the medium was adjusted to 5.7 with $0.5 \mathrm{M} \mathrm{NaOH}$ or $0.1 \mathrm{M} \mathrm{HCl}$, and the medium was autoclaved at 0.7 atmospheres $\left(120^{\circ} \mathrm{C}\right)$ for $20 \mathrm{~min}$, 
except for glutamine, which was filter-sterilized and added after autoclaving. The induction medium for immature zygotic embryos comprises basal medium, solid (8 g/L) agar and 2,4-dichlorophenoxyacetic acid (22.6 mM). At day 30, the explants were transferred to growth regulator-free medium for somatic embryo development [15]. Embryos cultured in this medium suffer a recurrent somatic embryogenesis process. Their embryogenic capacity remains stable; this stage was called proliferation stage (PSE). Embryos belonging to PSE are small embryos growing as

a pool (Fig. 1). Some embryos derived from PSE stop recurrent embryogenesis and result in individual, well shaped embryos with white cotyledons; this stage was called cotyledonar stage (CSE). Cotyledonar embryos turn into mature embryos (mature somatic embryos, MSE) after a period of 4 weeks at $25^{\circ} \mathrm{C}$ followed by 8 weeks at 4 $\stackrel{\circ}{ }$, in basal culture medium plus $1 \%$ activated charcoal.

\section{Protein extraction}

Embryos belonging to four $Q$. suber somatic embryos clonal were obtained from in vitro culture plates. Four protein extract replicate samples were prepared for each time point (PSE, CSE and MSE). Tissues from 30 individuals were taken for each replicate and grounded to a fine powder under liquid nitrogen before protein extraction. Samples were resuspended with Lysis Buffer (7M Urea, 2M Thiourea, 4\% CHAPS, 30mM Tris- $\mathrm{HCl}$, $\mathrm{pH} 8.5$ at $4^{\circ} \mathrm{C}$ ) plus $50 \mathrm{mM}$ DTT, followed by phenol extraction coupled with ammonium acetate-acetone precipitation [16]. Proteins were precipitated with Clean-Up Kit (GE Healthcare), the pellets were resuspended in Lysis Buffer, and the $\mathrm{pH}$ adjusted to 8.5 at $4^{\circ} \mathrm{C}$ when necessary. Protein concentration was measured with the RCDC Protein Assay Kit (Bio-Rad) for subsequent analysis by $2-\mathrm{DE}$. 


\section{D-DIGE separation}

The protein extracts were labelled with CyDye minimal dyes Cy2, Сy3 or Cy5 following the manufacturer's recommendations (GE Healthcare). Briefly, each protein extract $(50 \mu \mathrm{g})$ was independently labelled in the dark for 30 min at $0 \stackrel{\circ}{ } \mathrm{C}$ with 400 pmol of the cyanine dyes Cy3 or Cy5 dissolved in 99.8\% DMF (Sigma). The internal standard, the mixture of all the protein extracts, was labelled with Cy2 accordingly. The labelling reaction was quenched with $1 \mu \mathrm{L}$ of a $10 \mathrm{mM} \mathrm{L-Lysine} \mathrm{solution} \mathrm{(Sigma)}$ and left on ice 10min. After labelling and quenching, protein samples (PSE, CSE, MSE and internal standard) were mixed adequately in Rehydration Buffer (7M urea, 2M thiourea, 4\% CHAPS) containing 0.8\% IPG Buffer 3-11 non-linear (NL) and $50 \mathrm{mM}$ DTT.

Samples were then applied via cup-loading to $24-\mathrm{cm}$, pH 3-11 NL Immobiline DryStrips previously rehydrated in the aforementioned Rehydration Buffer containing 0.8\% IPG Buffer 3-11 NL and 1.2\% DeStreak (GE Healthcare). IEF was performed using an IPGphor ${ }^{\mathrm{TM}}$ || electrophoretic system (GE Healthcare) until steady state (32 $\mathrm{kVh}$ ). The strips were then incubated in SDS equilibration buffer (30\% v/v Glycerol; 75mM Tris-HCl, $\mathrm{pH} 8.8 ; 2 \%(\mathrm{w} / \mathrm{v}) \mathrm{SDS} ; 0.01 \%$ (w/v) Bromophenol Blue; 6M Urea) in two steps: first with $1 \%(\mathrm{w} / \mathrm{v})$ DTT for $15 \mathrm{~min}$, and second with $4 \%(\mathrm{w} / \mathrm{v})$ iodoacetamide for $15 \mathrm{~min}$. Finally, the strips were applied to vertical $12.5 \%$ SDSpolyacrylamide gels-and second dimension electrophoresis was carried out in an Ettan DALT Six apparatus (GE Healthcare) at $2 \mathrm{~W} / \mathrm{gel}$ for $1 \mathrm{~h}$ and $100 \mathrm{~W} / \mathrm{gel}$ until the tracking dye had migrated off the bottom of the gel.

\section{Image acquisition and analysis}


After SDS-PAGE, the gels were scanned using a TyphoonTM 9400 Imager (GE Healthcare) using appropriate wavelengths and filters for Cy2, Cy3, and Cy5 dyes according to the manufacturer's protocol to ensure a linear response. Images were subjected to automated analysis by differential in-gel analysis (DIA) and biological variation analysis (BVA) modules of the DeCyder differential analysis software, release 7.0 (GE Healthcare).

After examination of the automatic analysis, the DeCyder module EDA v1.0 (extended data analysis) provided additional statistical analysis of samples using Student's t-test and multivariate analysis. PCA hierarchical clustering was performed using the EDA module with Euclidean distance and average linkage settings.

For further MS analysis, those proteins with more than twofold expression level changes, high statistical significance ( $p \leq 0.05)$ and present in all the gels were selected. After fluorescence scanning of gels, an MS compatible silver staining protocol [14] was performed prior to spot picking.

\section{MS-based protein identification}

Protein spots were excised manually and then subjected to automated tryptic digestion using a Proteineer DP protein digestion station (Bruker-Daltonics, Bremen, Germany) and the resulting digestion solutions were analyzed on an Ultraflex TOFTOF mass spectrometer (Bruker-Daltonics) to obtain the corresponding MALDI-MS and MS/MS spectra as described previously [17]. The mass data were combined through the BioTools 3.0 program (Bruker-Daltonics) to search the non-redundant protein database NCBInr $20100430\left(2 \times 10^{7}\right.$ entries; National Center for Biotechnology Information, Bethesda, USA) using Mascot 2.2 software (Matrix 
Science, London, UK) [17]. MALDI-MS and MS/MS spectra and database search results were manually inspected in detail using the flexAnalysis 2.2 programs (Bruker-Daltonics) and archived and organized using home-made software.

\section{Biological function}

Information about the proteins differentially regulated across PSE, CSE and MSE samples was retrieved from different servers (RCSB Protein Data Bank, Babelomics, ExPASy, IHOP and EBIMed) containing information from the main protein databases publicly available. 


\section{RESULTS}

We have compared the proteome of proliferating, cotyledonar and mature somatic embryos from cork-oak. Proliferating embryos are embryogenic masses compound by globular, torpedo, heart-shaped and preliminary cotyledonar embryos up to five millimetres which can undergo secondary embryogenesis. On the other hand, cotyledonar embryos show well defined shape, both cotyledons and embryo axis, while mature somatic embryos, hard and yellowish, originate from cotyledonar embryos upon maturation. These embryos have the capacity to germinate and become plants.

The protein extracts from these diverse-paired samples of $Q$. suber somatic in vitro culture-derived embryos were analyzed by DIGE, which allowed circumventing some limitations of the conventional 2-DE approach, namely experimental variability by loading different samples at the same gel, and reduced dynamic range by using fluorescent labelling. Inter-gel analysis and quantification of spot volume is notably improved owing to the addition of an internal standard and the multiplexing capacity [18]. Statistical analysis of gels allowed the detection of 62 spots with significant changes between PSE and CSE, PSE and MSE and between CSE and MSE. These 62 regulated protein spots were excised from silver-stained gels, digested with trypsin and subjected to MALDI-MS analyses followed by database searching. A total of 44 protein spots (71\%) yielded positive protein identification (Table 1$)$, a moderate percentage which can be accounted for by the misrepresentation of protein sequences from $Q$. suber or other high-homology organisms in publicly available databases. Seven spots were identified as hypothetical proteins from Vitis vinifera, and another one as a predicted protein from Populus trichocarpa. After 
BLAST analysis, six of the seven and the protein from $P$. Trichocarpa were recalled with a $94 \%$ similarity (Table 1 ).

The differential proteomic analysis of PSE and CSE somatic embryos revealed 19 regulated proteins, eight of which showed substantially increased in the proliferating embryos, while the comparison of PSE and MSE somatic embryos showed 33 proteins, 13 of which were increased in the proliferating embryos. With respect to the comparison between CSE and MSE embryos, ten proteins showed regulated, of which three were up-regulated in the cotyledonar embryos; finally, the comparison between proliferating and joined CSE and MSE embryos revealed nine proteins upregulated in the immature embryos.

Using publicly available data, clustering of transcript data for these sets of proteins was performed, revealing a wide variety of expression patterns across proliferating, cotyledonar and mature embryos. According to their regulation patterns across PSE, CSE and MSE stages, proteins were classified into eight types (Table 1 and Figure 2). Type-1 and -2 members correspond to proteins found up- and down-regulated, respectively, between PSE and CSE. Type-3 and -4 proteins showed up- and downregulated, respectively, between CSE and MSE, whereas type-5 and - 6 members were found up- and down-regulated, respectively, between PSE and MSE, and type7 and -8 proteins revealed up- and down-regulated, respectively, between proliferating and joined CSE and MSE embryos.

\section{Classification of the proteins identified}

To integrate protein expression data into functional categories, a classification of the proteins found regulated was carried out based on their GO terms. This produced 
five main functional groups (Fig. 3): ROS detoxification and stress response (17 proteins, 38.6\%), cell division (12 proteins, 31.8\%), storage reserves (6 proteins, $31.8 \%$ ), glycolysis (6 proteins, $15.8 \%$ ), and polyamine and ethylene biosynthesis ( 3 proteins, $8 \%$ ).

\section{DISCUSSION}

The development of efficient protocols for somatic and gametic embryogenesis in $Q$. suber [1] has influenced many areas of woody plant research, and has greatly facilitated comparative proteomic studies of somatic and gametic in vitro derived embryos [10]. In this study the DIGE/MS analytical platform has facilitated the sensitive, quantitative analysis of proteins which undergo regulation along the different stages of the embryogenic process. According to their biochemical functions, most of these proteins were classified as ROS detoxification and stress response proteins, followed by proteins involved in cell division, storage reserves, glycolysis, and polyamine and ethylene biosynthesis.

\section{Proteins involved in ROS detoxification and stress response}

Manganese superoxide dismutase (MnSOD; spot 1) levels increased from initial to cotyledonar and mature stages. MnSOD is localized exclusively in the mitochondrial matrix, where it constitutes the major ROS detoxifying enzyme. Low levels of this enzyme diminish the antioxidant capacity of the cell, which can influence homeostasis. MnSOD catalyzes the dismutation of superoxide radicals to molecular oxygen and hydrogen peroxide. Other enzymes like ascorbate peroxidase, catalase, thioredoxin fold, 2-cys peroxiredoxin, and glutathion S-transferase decompose hydrogen peroxide generated by SODs to water. 
Thus, ascorbate peroxidase (spot 2) catalyses electrons transfer from ascorbate to the peroxide group, producing dehydroascorbate $(\mathrm{DHA})$ and water. This results in increased DHA and, consequently, reduced AA/DHA ratio, which characterizes mature embryos. Results indicate increased ascorbate peroxidase level in mature embryos as compared to previous stages, with a slight decrease in intermediate stages as compared to the initial stage. Increased expression of ascorbate peroxidase has been reported for mature embryos in dry seeds [19]; the enzyme is involved in ROS detoxification in plants where ascorbate is the predominant nonenzymatic antioxidant acting as a co-substrate [20].

Likewise, catalase (spot 3) showed a similar expression pattern than ascorbate peroxidase, with diminished levels in proliferating embryos and increased abundance in the mature ones. In agreement with this observation, Kairong et al. [21] demonstrated not only that catalase activity is low in the early days of differentiation in somatic embryos of Lycium barbarum, but also that the inhibition of catalase activity increased the frequency of somatic embryogenesis.

Thioredoxin fold (spot 4) showed increased level upon maturation. The ubiquitous thioredoxin protein group regulates many posttranscriptional biological functions in eukaryotic cells and is involved in reserve breakdown, which sustains early seedling growth [22]. Thioredoxin fold is able to donate electrons to detoxify such ROS as hydrogen peroxide to oxygen and water, and has the capacity to maintain redox balance among various cellular proteins such as ribonucleotide reductase.

Another protein found up-regulated at the final stages of somatic embryogenesis is 2-cys peroxiredoxin (spot 5). Increased expression of this protein has been found in the late developing seeds of Medicago truncatula [6] as well as under Pi deprivation 
in Arabidopsis [23]. Recently, members of the 2-Cys peroxiredoxin family were identified as components of the antioxidant defence system of chloroplasts [24]. The peroxiredoxin-mediated detoxification pathway represents an alternative metabolic pathway of the water/water cycle to ascorbate, where reduced peroxiredoxin activities would increase the oxidation state of the ascorbate pool and vice versa [25]. The activity of chloroplast 2-cys peroxiredoxin would affect fatty acid signalling by compounds such us thaumatin (spot 15) [26].

Formate dehydrogenase (spot 6) level was found augmented in mature embryos, which resemble seeds more closely. This enzyme, which produces $\mathrm{CO}_{2}$ from formate, is highly expressed in seeds and detectable in the perisperm [27]. It is implicated in stress response [28] and was found located in mitochondria in Q. robur [29]. Formate dehydrogenase is more abundant in non-photosynthetic tissues, which could be related to differences in the mitochondrial function [30].

Quinone reductase (spot 7) is accumulated during embryo maturation. Browning of explant tissues and culture medium is assumed to be due to oxidation of polyphenols and formation of quinines. The inhibitory effects in cultures may result from the bonding of phenols with proteins and their subsequent oxidation into quinines. Reduction of electrophilic quinones by quinone reductase is an important detoxification pathway.

Proteasome subunit alpha type (spot 8 ) is accumulated during embryo maturation. ROS-damaged intracellular proteins could be degraded by this proteolytic enzyme [31]. 
A member of the Hsp70 family (spot 9) showed increased abundance in mature somatic embryos as compared to their immature (PSE and CSE) counterparts. The Hsp70 family is made up of molecular chaperones involved in a variety of cellular processes including protein folding, protein transport across membranes, modulation of protein activity, regulation of protein degradation and prevention of irreversible protein degradation. The Hsp70 family is implicated in embryo development protection [32] through the prevention of protein aggregation and the renaturation of aggregated proteins during the oxidative stress to which the seed (mature embryo in this case) is exposed [33]. Developmentally regulated expression of the Hsp70 in Arabidopsis mature dry seed in the absence of stress suggests prominent roles in seed maturation for this member of the Hsp70 family [34]. Furthermore, Hsp70binding protein (spot 10) showed the opposite trend as was reported by Lippert et al. [7]. This protein could be a Hsp-70-interacting protein for substrate interaction and regulation of ATP hydrolysis [35], preventing ATP binding to Hsp70 inhibiting Hsp70 chaperone activity [36].

In view of the low levels of the above proteins found at the first embryo proliferation steps, other enzymes could be expected to carry out the removal of the hydrogen peroxide produced by cell metabolism. Thus, glutathione-S transferase (spot 11), involved in the limitation of oxidative damage and other stress responses in plants, could play a ROS detoxification role in the proliferation stage, as suggested by the observed regulation profile of this enzyme.

In general, cinnamyl alcohol dehydrogenase (CAD; spot 12) genes are expressed preferentially in the primary xylem vessels in young regions of the stem and in the xylem rays in more mature regions of the stem [37]. CAD has been proposed as a 
molecular marker specific for lignin synthesis [38], despite that high levels of CAD were found in nonlignifying seed tissues from loblolly pine [39]. lyer et al. [40] revealed the presence of compounds similar to lignans in the embryogenic mass. In addition, Coelho et al. [41] identified a gene encoding a potential NADPH-dependent CAD in $Q$. suber, which suggests that this enzyme belongs to a new group of cinnamyl alcohol dehydrogenases potentially involved in deactivation of toxins produced by pathogens. This study shows up-regulation of the enzyme at the first stage of somatic embryo development, which suggests a role for this protein in stress response during this phase.

ATP-binding protein (spot 13) is another HSP that showed increased abundance in the initial embryo stage (PSE). This protein controls protein folding during cell reorganization from somatic plant cells to embryogenic pathway [42]. The ATPdependent chloroplast protease (spot 14) incorporates the activity of molecular chaperones to target specific polypeptide substrates and avoid inadvertent degradation of others [43]. This protein showed lower abundance at CSE than at PSE and MSE. It could be related with the final differentiation and the loss of chloroplast functionality in these cells.

Two PR5 proteins were identified with maximum abundance at initial embryo stage. Both followed a significant decreasing trend from PSE to MSE through CSE embryos. One of them is thaumatin (spot 15) and the other one is an osmotin-like protein called Quercus robur xylem protein (spot 16). Thaumatins, implicated in diverse physiological and developmental processes including embryogenesis, have been identified in maize microspore embryonic suspension cultures and also in barley [44] and wheat [45] seeds. Thaumatins are PR proteins capable of binding 
and hydrolyzing $\beta-1,3$-glucans [46] and releasing oligosaccharides. $\beta$-1,3-glucans are fundamental in early stages of microspore embryogenesis [47]. Thaumatin is supposed to mediate cell fate [48] and help to establish their embryonic competence and/or to direct enlargement and further development of the embryo [49]. Quercus robur xylem protein is a protein from cork oak phellen tissue (cork cells), and its accumulation could be correlated with the somatic embryogenesis process in Quercus suber [50]. Nevertheless, in this study the abundance levels of Quercus robus xylem were the lowest at the mature somatic embryo developmental stage.

Auxin-induced protein PCNT115 (spot 17) showed the highest expression level at mature stage. This protein belongs to a family of aldo/keto reductase (AKR) and is stimulated by stress. The primary role of AKR may be to detoxify a range of toxic compounds produced during stress [51]. Similar expression patterns have been found for AKR proteins at the precotyledonary stage in Acca sellowiana [52] and at the mature embryo stage in Citrus sinensis [53].

ROS and enzymes implied in the antioxidant defence have been proposed as components of signalling pathways [54]. The exposure of cells to low levels of hydrogen peroxide stimulates proliferation, and Kairong et al. [21] demonstrated that increased levels of intracellular hydrogen peroxide induced and promoted somatic embryogenesis, whereas in the proliferation stage less ROS scavenging systems were switched on.

\section{Proteins involved in cell division}

Cell cycle proteins regulate processes as diverse as cell division and cell death. RNA-binding protein (spot 18) showed up-regulated in proliferating embryos. RNA- 
binding proteins play key roles in post-transcriptional control of RNAs, which, along with transcriptional regulation, is a major way to regulate patterns of gene expression during development. These proteins have shown to be involved in spermatogenesis, embryogenesis and cell-cycle progression [55]. Likewise, the expression of an RNAbinding protein was found restricted to pollen and ovule development and early embryogenesis in Arabidopsis [56]

Phosphate binding-protein (spot 19) is elevated under Pi deprivation. This protein is predominant at the early stage of embryogenesis (PSE). Phosphorus is an important modulator of gene expression in plants, and thus, nutritional Pi status has a major influence on the levels of various membrane transporters and enzyme proteins. Phosphate starvation modulates some genes related with phytohormone regulation. Phosphate binding-protein is a putative cell division control protein through auxin regulation (TIR1 auxin receptor is specifically induced in response to Pi-deprivation). Auxins play a central role in the first embryogenesis phase, characterised by a high cell division rate.

Two 14-3-3 proteins (spots 20 and 21) were more abundant in proliferating embryos than in their mature counterparts. The 14-3-3 protein family has been shown to play regulatory roles in eukaryotic cells, including cell cycle control and differentiation, and is known to bind the regulators during interphase but not during mitosis [57]. Instead of directly activating or inhibiting the cell cycle, the 14-3-3 protein family modulates interactions between components of signal transduction pathways, for which the regulators need to be phosphorylated [58], and their response to $\mathrm{Pi}$ deprivation is moderate [59]. 
Three alpha-tubulin proteins (spots 22, 23 and 24) have been detected. Alphatubulin had been previously identified in $Q$. ilex [60] and $Q$. robur [61], and was found upregulated in Q.suber in vitro derived gametic embryos [10]. This cytoskeletal protein was down-regulated upon maturation in agreement with the corresponding activity measured in diverse embryogenesis stages in Picea abies [7], and its activity is triggered at the start of the cell cycle after seed imbibing (i.e. pea germination; [62]). Alpha-tubulin makes up microtubules, involved in nuclear and cell division, organization of cell structure and intracellular transport. Alpha-tubulin isoforms may be functionally distinct, and alpha-tubulin 4 (spot 24; up-regulated only in cotyledonar embryos) may affect microtubule stability [63]. Previous results in Populus [64] are consistent with the involvement of alpha-tubulin 4 in secondary cell wall development.

Another two enzymes, chalcone isomerase (spot 25) and flavanone 3-hydroxylase (spot 26), catalyze the reaction between chalcones and flavanones and between flavanones and dihydroflavonols, respectively, in the phenylpropanoid and flavonoid biosynthesis pathway. The basic skeleton of flavonoids is generated by the enzymes chalcone synthase and chalcone isomerase. The different flavonoids have a multitude of biological functions including auxin transport. Flavonoids have been suggested to be endogenous auxin transport inhibitors based on their activity in vitro [65] and in vivo [66]. It can be hypothesized that the inhibition of auxin transport is the role of chalcone isomerase and flavanone 3-hydroxylase at the cotyledonar and mature embryo stages, where they are up-regulated.

Also, dehydroascorbate reductase (spot 27) was found up-regulated in mature embryos. This enzyme is implicated in the ascorbate metabolism. Ascorbate is 
involved in the regulation of cell elongation and progression through the cell cycle [67]. The arrest of the cell cycle in the G1 phase is prevented by exogenous ascorbic acid administration, which prevents and reverses inhibition in cell division [68]. Hence, ascorbate accelerates the onset of cell proliferation due to an increased proportion of cells progressing through the $\mathrm{G} 1 / \mathrm{S}$ transition. During cell division and cell expansion ascorbate consumption is more or less the same; however the ascorbic acid/dehydroascorbic acid (AA/DHA) ratio is 6-10 during cell division and 13 during cell expansion. This ratio has a role in determining exit from the cell division cycle and part of the ascorbate response depends on their pool quantities [69]. Ascorbate acts in the cell metabolism as an electron donor, and consequently ascorbate free radical (AFR) is continuously produced. AFR can be reconverted to AA by means of ascorbate reductase or can undergo spontaneous disproportion, thus generating dehydroascorbic acid (DHA). Furthermore, DHA is a toxic compound for the cell metabolism. Therefore cells have various strategies to counteract its effects, whereas cells from PSE or expanding cells from more mature embryos, which contain low levels of ascorbate reductase, are provided with a developed vacuolar system to segregate the toxic DHA in the vacuole [68]. Then vacuolar $\mathrm{H}$ ATPase (spot 28) protein drives osmotic uptake of water into the central vacuole playing an important role in cell expansion [70]. This protein is more abundant at MSE.

Dihydroxyacetone kinase (spot 29) catalizes the phosphorylation of 3,4-dihydroxy-2butanone to 3,4-dihydroxybutanone-4-phosphate which is transformed by way of the usual intermediates into a polysaccharide [71], furthermore 3,4-dihydroxybutanone4-phosphate is an intermediate of riboflavin biosynthesis which has stimulative effects on plant somatic embryogenesis [72] for PSE. 


\section{Proteins involved in storage reserves}

The cotyledons are the food stores of $Q$. suber seed. They contain protein, fat, and starch which provide energy for the developing seedling. Results indicate that there is a clear pattern of increased storage reserves from proliferating to cotyledonar embryos coinciding with the development of the cotyledons (reserve organs in the seed) and later from this stage to the mature one.

Starch phosphorylase (spot 30 ) is a plastidic phosphorylase which appears to be associated with the initiation of seed endosperm reserve starch accumulation [73]. For example, in the early cotyledon stage, oilseed rape embryos used sucrose predominantly for starch synthesis [74]. This enzyme catalyzes the reversible transfer of glucosyl units from glucose-1-phosphate to the non-reducing end of alpha-1,4-D-glucan chains with the release of phosphate. By the action of starch phosphorylase small malto-oligosaccharides (D-glucose units), which are generated in the plastid, diffuse into the starch granule where they are elongated processively by granule bound starch (spots 31 and 32 ) to a size that is too great to allow them to diffuse readily out of the granule matrix. They thus become the amylase component of the granule in the starch production. Granule bound starch abundance is higher in mature $Q$. suber in vitro derived embryos, which is in agreement with the high activity detected in pea seed mature embryos for this protein [75]. Furthermore, starch accumulation was significantly higher in somatic torpedo and cotyledonary embryos than in the corresponding zygotic ones in conifers [76].

Despite that the abundance of granule bound starch and legumin precursor (spot 33) peak at similar times in the embryogenic process, the latter is down-regulated in the CSE-MSE phase change. Legumin precursor is highly abundant in globular and 
cotyledonar embryos, and has been found up-regulated in the mature in vitro derived embryo tissue of Picea abies [7]. Legumin precursor activity reduction in the last embryo developmental phase (MSE) coincides with an increase in legumin (spot 34) expression. Legumin is a legumin-like protein previously described in Quercus suber embryos [77]. In some species the level of this type of reserve proteins has been used to distinguish between zygotic and somatic embryos [78] due to a lower accumulation of reserve proteins in somatic embryos.

Cysteine synthase (spot 35) resulted up-regulated in cotyledonar compared with mature embryos. A positive correlation was found between the specific activity of the terminal enzyme of cysteine synthesis, cysteine synthase, and the cysteine content of seeds [79]. Furthermore, cysteine synthase activities also discriminate the embryogenic calli from non embryogenic calli [80].

Deposition of storage compounds (basically storage proteins and starch) prevails in later embryogenesis stages. In fact the growing embryo evolves from accumulating metabolic (expanding) compounds to storing reserve compounds.

\section{Enzymes related with glycolysis}

Carbohydrates are of prime importance for cell growth, maintenance and differentiation in vitro. Plant cell and tissue culture metabolize sucrose to provide energy and carbon skeletons for every metabolic process that the cell will conduct. The enzymes related to the glycolysis (the metabolic pathway that converts glucose into pyruvate) and citric acid cycle are correlated with cellular ATP utilization in higher plants [81]. In this study six enzymes involved in glycolysis were found regulated: $\alpha$-glucosidase, triosephosphate isomerase, serine 
hydroxymethyltransferase, glyceraldehyde-3-phosphate dehydrogenase (GAPDH), pyruvate decarboxilase and alcohol dehydrogenase.

Alpha-glucosidase (spot 36) is an enzyme from starch-storing organs. In contrast to other starch-degrading enzymes, $\alpha$-glucosidases have the unique property of flexible substrate specificity; they are capable of hydrolyzing $\alpha$-D-glucosides ( $p$-nitrophenylalpha-D-glucoside and methyl-alpha-D-glucoside), oligosaccharides (maltodextrins), and polysaccharides (amylose, amylopectin, and glycogen). Alpha-glucosidase was found up-regulated in CSE and MSE embryos, when starch is available after accumulation in cotyledons.

Triosephosphate isomerase (spot 37), the glycolytic enzyme that catalyses the reversible interconversion of dihydroxyacetone phosphate and glyceraldehyde 3phosphate, plays key roles in several metabolic pathways and efficient energy production. Serine hydroxymethyltransferase (spot 38) catalyses the reversible interconversion of serine to glycine. Serine is synthesised from 3-phospho-Dglycerate, the product of GAPDH (spot 39) within glycolysis. The opposite trend was found in the expression pattern of GAPDH, whose abundance increased at PSE, peaked at CSE and decreased at MSE. GAPDH catalyzes the conversion of glyceraldehyde-3-phosphate to 1,3-bisphosphoglycerate. Results indicate that CSE is more demanding in terms of energy and precursors for the synthesis of primary metabolites such as amino acids and fatty acids [74]. All three proteins, serine hydroxymethyltransferase, GAPDH and triosephosphate isomerase are specifically induced in somatic embryos [82, 83], although their distinct expression patterns could reflect regulation along the glycolisis pathway at different developmental stages. 
Pyruvate decarboxilase (spot 40) uses pyruvate as a substrate, and is associated with the outer membranes of mitochondria, suggesting that such microcompartmentation of glycolysis allows pyruvate to be provided directly into the mitochondrion [84]. It is the first enzyme in the pyruvate dehydrogenase complex, and serves to generate acetyl-CoA, which is essential during embryo development. We found decreased level of this enzyme at MSE as compared to PSE, where pyruvate decarboxilase may lessen energy needs before starch accumulation has taken place; nevertheless, Wurtele et al. [85] failed to observe any significant changes in the activity of this enzyme in response to somatic embryo development in carrot. In fact, pyruvate is a compound at the branch point between aerobic and anaerobic metabolism. Under anaerobic conditions, pyruvate decarboxilase converts pyruvate to the neutral species acetaldehyde and ethanol. Alcohol dehydrogenase (spot 41) showed the same regulation pattern than pyruvate decarboxilase, probably to reduce the toxic effects of ethanol.

\section{Proteins involved in polyamines and ethylene biosynthesis}

Continued biosynthesis of polyamines is an essential aspect of the metabolism during the differentiation and development of somatic embryos in plants. Three of the proteins found regulated participate in methionine metabolism: two methionine synthetases (spots 42 and 43; one of them Sal K3 pollen allergen) and 5methyltetrahydropteroyltriglutamate--homocysteine methyltransferase (MTHP; spot 44). These enzymes showed increasing levels along the embryo maturation process. The last step in methionine synthesis is localized in the cytosol [86], catalysed by methionine synthetase using glutamine. Low amounts of this enzyme are present in plants, in particular in dry mature seeds, where it exerts mainly metabolism control 
functions [87] and is required for cell wall formation [88]. MTHP catalyzes the formation of methionine by transferring a methyl group from 5-

methyltetrahydropholate to homocysteine. Methionine is the immediate precursor of 5-adenosyl-methionine, which acts as a major group donor in transmethylation reactions and as an intermediate in the biosynthesis of polyamines and ethylene. The pathway for polyamine biosynthesis shares this common precursor with the biosynthesis of ethylene in plants. Both increased polyamine synthesis and ethylene accumulation had been previously reported during somatic embryo development [7, 89]. Ethylene accumulation might control cotyledon expansion during embryo development [90], which would explain its increased level in the advanced stages of Q. suber somatic embryo development. Furthermore, inhibiting polyamine synthesis usually blocks embryo development [91]. Polyamines can counteract the auxin effect [92]. Auxins produce organized proembryogenic cell masses (act at the PSE) and can suppress the development of somatic embryos and thus the phase change from proliferating to mature embryos.

\section{CONCLUSIONS}

Somatic embryo at PSE, a cell proliferation stage, is characterized by up-regulation of proteins involved in cell division. In this stage ROS play a role in proliferation, while other proteins like CAD and PR5 seem to be implied in embryonic competence. Phase transition between PSE and CSE requires that cell division be replaced with cell expansion. Diverse ROS detoxification enzymes are then activated, and the accumulation of reserve products (mainly carbohydrates and proteins) is triggered. During MSE ethylene accumulation regulates embryo 
development. With respect to energy requirements, these reach a maximum at CSE, probably to produce primary metabolites such as amino acids and fatty acids, while fermentation could constitute an alternative source of energy at the early steps of somatic embryo development.

\section{FINANCIAL DISCLOSURE / ACKNOWLEDGEMENTS}

The Centro Nacional de Investigaciones Cardiovasculares is supported by the Spanish Ministerio de Economía y Competitividad and the Fundación Pro-CNIC.

The authors have no other relevant affiliations or financial involvement with any organization on entity with a financial interest in or financial conflict with the subject matter or materials discussed in the manuscript apart from those disclosed.

No writing assistance was used in the production of this manuscript.

\section{REFERENCES}

1. Bueno MA, Gómez A, Manzanera JA. Somatic and gametic embryogenesis in Quercus suber L. In: Jain SM, Gupta PK, Newton RJ, editors. Somatic Embryogenesis in Woody Plants. Forestry Sciences, vol 6. ISBN 0-79236419-8. Kluwer Academic Publishers, Dordrecht/Boston/London; 2000, p. 479-508.

2. Dyachok JV, Wiweger M, Kenne L, van Arnold S. Endogenous Nod-factor-like signal molecules promote early somatic embryo development in Norway spruce. Plant Cell Rep 2000; 19: 290-297.

3. Footitt S, Ingouff M, Clapham D, von Arnold S. Expression of the viviparous I (Bavpl) and $\mathrm{p} 34 \mathrm{cdc} 2$ protein kinase (cdc2Pa) genes during somatic embryogenesis in Norway spruce (Picea abies (L.) Karst). J Exp Bot 2003; 54: 1711-1719. 
4. Stasolla C, Kong L, Yeung EC, Thorpe TA. Somatic embryogenesis in conifers: morphogenesis, physiology, biochemistry, and molecular biology. In Vitro Cell Dev Biol 2002; 38:93-105.

5. Stasolla C, Bozhkov PV, Chu TM, Van Zyl L, Egertsdotter U, Suarez MF, Craig D, Wolfinger RD, Von Arnold S, Sederoff RR. Variation in transcript abundance during somatic embryogenesis in gymnosperms. Tree Physiol 2004; 24(10):1073-85.

6. Imin N, Nizamidin M, Daniher D, Nolan KE, Rose RJ, Rolfe BG. Proteomic analysis of somatic embryogenesis in Medicago truncatula explant cultures grown under 6-Benzylaminopurine and 1-Naphthaleneacetic Acid treatments. Plant Phys 2005; 137 (4):1250-1260.

7. Lippert D, Zhuang J, Ralph S, Gilbert $M$ et al. Proteome analysis of early somatic embryogenesis in Picea glauca. Proteomics 2005; 5: 461-473.

8. Sghaier-Hammami B, Valledor L, Drira N, Jorrin-Novo JV. Proteomic analysis of the development and germination of date palm (Phoenix dactylifera L.) zygotic embryos. Proteomics 2009; 9:2543-2554.

9. Kaufmann K, Smaczniak C, de Vries S, Angenent GC, Karlova R. Proteomics insights into plant signaling and development. Proteomics Special Issue, 2011; 11 (4): 744-755.

10. Gomez A, Lopez JA, Pintos B, Camafeita E, Bueno MA. Proteomic analysis from haploid and diploid embryos of Quercus suber $\mathrm{L}$. identifies qualitative and quantitative differential expression patterns. Proteomics 2009; 9:43554367.

11. Winkelmann T, Heintz D, Van Dorsselaer A, Serek M, Braun HP: Proteomic analyses of somatic and zygotic embryos of Cyclamen persicum Mill. reveal new insights into seed and germination physiology. Planta 2006; 224:508519.

12. Bueno MA, Astorga R, Manzanera JA. Plant regeneration through somatic embryogenesis in Quercus suber L. Physiol Plant 1992; 85, 30-34.

13. Sommer H E, Brown CL, Kormanik PP. Differentiation of plantlets in longleaf pine (Pinus palustris Mill.) tissue cultured in vitro. Bot Gaz 1975; 136:196200.

14. Murashige T, Skoog F. A revised medium for rapid growth and bioassays with tobacco tissue cultures. Physiol Plant 1962; 15: 473-497.

15. Manzanera JA, Astorga R, Bueno MA. Somatic embryo induction and germination in Quercus suber L. Silvae Genet 1993; 42:90-93.

16. Isaacson T, Damasceno C, Saravanan RS, He Y et al. Sample extraction techniques for enhanced proteomic analysis of plant tissues. Nat Protoc 2006; 1:769-774.

17. Suckau D, Resemann A, Schuerenberg M, Hufnagel P et al. A novel MALDI LIFT-TOF/TOF mass spectrometer for proteomics. Anal Bioanal Chem 2003; 376:952-965.

18. Alban A, David SO, Bjorkesten L, Andersson C et al. A novel experimental design for comparative two-dimensional gel analysis: two-dimensional 
difference gel electrophoresis incorporating a pooled internal standard. Proteomics 2003; 3:36-44.

19. Gong H, Jiao Y, Hu W, Pua EH. Expression of glutathione-S-transferase and its role in plant growth and development in vivo and shoot morphogenesis in vitro Plant Molec Biol 2005; 57:53-66

20. Dietz KJ. The dual function of plant peroxiredoxins in antioxidant defence and redox signaling. In: Flohé L, Harris JR, editors. Peroxiredoxin Systems. Springer; 2007, p. 267-294.

21. Kairong C, Gengshenga X, Xinminb L, Gengmeia X, Yafu W. Effect of hydrogen peroxide on somatic embryogenesis of Lycium barbarum $L$. Plant Sc 1999; 146 (1): 9-16.

22. Gelhaye E, Rouhier N, Jacquot J-P. The thioredoxin h system of higher plants. Plant Physiol Biochem 2004; 42:265-271.

23. Kandlbinder A, Finkemeier I, Wormuth D, Hanitzsch M, Dietz KJ. The antioxidant status of photosynthesising leaves under nutrient deficiency: redox regulation, gene expression and antioxidant activity in Arabidopsis thaliana. Physiol Plant 2004; Special Issue on Redox Regulation, 120: 63-73.

24. Dietz KJ. Peroxiredoxins in plants and cyanobacteria. Antioxid Redox Sign 2011; 15: 1129-1159.

25. Dietz KJ, Horling F, König J, Baier M. The function of the chloroplast 2cysteine peroxiredoxin in peroxide detoxification and its regulation. $J$ Exp Bot 2002; 53 (372): 1321-1329

26. Mahmood T, Jan A, Komatsu S. Proteomic analysis of bacterial blight defence signalling pathway using transgenic rice overexpressing thaumatin-like protein. Biol Plantarum 2009; 53 (2): 285-293.

27. Catusse J, Strub JM, Job C, Van Dorsselaer A, Job D. Proteome-wide characterization of sugarbeet seed vigor and its tissue specific expression. PNAS 2008; 105:10262-10267.

28. David P, des Francs-Small CC, Sevignac M, Thareau V, Macadre C, Langin $T$, Geffroy V. Three highly similar formate dehydrogenase genes located in the vicinity of the B4 resistance gene cluster are differentially expressed under biotic and abiotic stresses in Phaseolus vulgaris. Theor Appl Genet 2010; DOI 10.1007/s00122-010-1293-x

29. Krüger A , Skan-Berghöfer TP, Frettinger $P$, Herrmann S, Buscot F, Oelmüller R. Identification of premycorrhiza-related plant genes in the association between Quercus robur and Piloderma croceum New Phytologist 2004; 163 : 149-157.

30. Bowsher CG, Tobin AK. Compartmentation of metabolism within mitochondria and plastids. Journal of experimental botany 2001; 52(356): 513-27.

31. Huanga $\mathrm{H}$, Møllerc IM, Songa SQ. Proteomics of desiccation tolerance during development and germination of maize embryos. Journal of proteomics 2012; 1247-1262.

32. Wehmeyer N, Vierling E. The expression of small heat shock proteins in seeds responds to discrete developmental signals and suggests a general 
protective role in desiccation tolerance. Plant Physiology 2000; 122:1099_ 1108.

33. Pawłowski, TA. Proteomic approach to analyze dormancy breaking of tree seeds Plant Mol Biol 2010; 73:15-25.

34. Sung DY, Kaplan F, Guy CL. Plant Hsp70 molecular chaperones: Protein structure, gene family, expression and function. Physiologia Plantarum 2001; 113 (4): 443-451.

35. Hahn A, Bublak D, Schleiff E, Scharf KD. Crosstalk between Hsp90 and Hsp70 chaperones and heat stress transcription factors in tomato. Plant Cell $2011 ; 23(2): 741-55$.

36. Raynes DA, Guerriero V Jr. Inhibition of Hsp70 ATPase activity and protein renaturation by a novel Hsp70-binding protein. J Biol Chem 1998; 273:3288332888.

37. Fukuda $\mathrm{H}$. Xylogenesis: initiation, progression, and cell death. Annu Rev Plant Physiol Plant Mol Biol 1996; 47:299-325.

38. Walter MH, Grima-Pettenatit J, Grand C, Boudett AM, Lamb CJ. Cinnamylalcohol dehydrogenase, a molecular marker specific for lignin synthesis: cDNA cloning and mRNA induction by fungal elicitor. Proc Natl Acad Sci USA 1988; 85: 5546-5550.

39. O'Malley DM, Porter S, Sederoff RR. Purification, characterization, and cloning of cinnamyl alcohol dehydrogenase in loblolly pine (Pinus taeda L.) Plant Physiol 1992; 98: 1364-1371.

40. Iyer RI, Jayaraman G, Ramesh A. Direct somatic embryogenesis in Myristica malabarica Lam., an endemic, threatened medicinal species of Southern India and detection of phytochemicals of potential medicinal value Indian Journal of Science and Technology Indian J Sci Technol 2009; 2 (7):11-17.

41. Coelho, AC, Hortaa M, Nevesc D, Cravador A. Involvement of a cinnamyl alcohol dehydrogenase of Quercus suber in the defence response to infection by Phytophthora cinnamomi. Physiological and Molecular Plant Pathology 2006; 69:62-72.

42. Fehér A, Pasternak TP, Dudits $D$. Transition of somatic plant cells to an embryogenic state. Plant Cell, Tissue and Organ Culture 2003; 74(3):201228.

43. Zheng B, Halperin T, Hruskova-Heidingsfeldova O, Adam Z, Clarke AK. Characterization of Chloroplast Clp proteins in Arabidopsis: Localization, tissue specificity and stress responses. Physiol Plant. 2002; 114(1):92-101.

44. Ronald I W, Osmond MH, Fontaine F, Imberty A, Fincher GB. Binding interactions between barley thaumatin-like proteins and $(1,3)$-b-D-glucans Eur. J. Biochem. 2001; 268:4190-4199.

45. Yu L, Niu JS, Ma ZQ, Chen PD, Liu DJ. Cloning, mapping and protein expression of wheat thaumatin protein gene (TaTLP1). Yi Chuan Xue Bao. 2003; 30(1):49-55.

46. Trudel J, Grenier J, Potvin C, Asselin A. Several thaumatin-like proteins bind to beta-1,3-glucans.Plant Physiol. 1998; 118(4):1431-8. 
47. Malik MR, Wang F, Dirpaul JM, Zhou N, Polowick PL, Ferrie AMR, Krochko JE. Transcript Profiling and Identification of Molecular Markers for Early Microspore Embryogenesis in Brassica napus1. Plant Physiol. 2007; 144(1): 134-154.

48. McCabe PF, Valentine TA, Forsberg LS, Pennell RI. Soluble signals from cells identified at the cell wall establish a 1437 developmental pathway in carrot. Plant Cell 1997;9: 2225-2241.

49. Hanai H, Matsuno T, Yamamoto M, Matsubayashi Y, Kobayashi T, Kamada $\mathrm{H}$, Sakagami $\mathrm{Y}$. A secreted peptide growth factor, phytosulfokine, acting as a stimulatory factor of carrot somatic embryo formation. Plant Cell Physiol. 2000; 41: 27- 32.

50. Pla M, Huguet G, Verdaguer D, Puigderrajols P, Llompart B, Nadal A, Molinas M. Stress proteins co-expressed in suberized and lignified cells and in apical meristems Plant Science 1998; 139:49-57.

51. Simpson PJ, Tantitadapitak C, Reed AM, Mather OC, Bunce CM, White SA, Ride JP. Characterization of Two Novel Aldo-Keto Reductases from Arabidopsis: Expression Patterns, Broad Substrate Specificity, and an Open Active-Site Structure Suggest a Role in Toxicant Metabolism Following Stress. Journal of Molecular Biology 2009; 392(2): 465-480.

52. Cangahuala-Inocente GC, Steiner N, Maldonado SB, Guerra MP. Patterns of protein and carbohydrate accumulation during somatic embryogenesis of Acca sellowiana. Pesq. agropec. bras., 2009; 44(3): 217-224.

53. Pan Z, Guan R, Zhu S, Deng X. Proteomic analysis of somatic embryogenesis in Valencia sweet orange (Citrus sisnensis Osbeck). Plant Cell Reports 2009; 28(2): 281-289.

54. Bykova NV, Hoehn B, Rampitsch C, Banks T, Stebbing JA, Fan T, Knox R. Redox-sensitive proteome and antioxidant strategies in wheat seed dormancy control. Proteomics 2011; 11: 865-882. doi: 10.1002/pmic.200900810

55. Gendra E, Moreno A, Albà MM, Pages M. Interaction of the plant glycine-rich RNA-binding protein MA16 with a novel nucleolar DEAD box RNA helicase protein from Zea mays. The Plant Journal ; 38(6): 875-886.

56. Belostotsky DA, Meagher RB. A pollen-, ovule-, and early embryo-specific $\operatorname{poly}(A)$ binding protein from Arabidopsis complements essential functions in yeast. Plant Cell. 1996; 8(8):1261-75.

57. Meek SEM, Lane WS, Piwnica-Worms H. Comprehensive Proteomic Analysis of Interphase and Mitotic 14-3-3-binding Proteins. The Journal of Biological Chemistry 2004; 279: 32046-32054.

58. Dubois T, Howell S, Amess B, Kerai P, Learmonth M, Madrazo J, Chaudhri M, Rittinger K, Scarabel M, Soneji Y, Aitken A. Phosphorylation of target proteins as well as 14-3-3 are important for protein-protein interactions J. Protein Chem. 1997; 16: 513-522. 
59. Wang Y, Waldron RT, Dhaka A, Patel A, Riley MM, Rozengurt E, Colicelli J. The RAS effector RIN1 directly competes with RAF and is regulated by 14-3-3 proteins. Mol. Cell Biol. 2002; 22: 916-926.

60. Andre' s-Montaner D, Zimmer I, Steigner D, Fischbach RJ, Schnitzler JP. Monoterpene formation in evergreen leaves of Holm oak (Quercus ilex L.) is not affected by mechanical wounding. Geophys. Res. Abstr. 2006; 8: 02-07.

61. Nogues I, Louis S, Fortunati A, Loreto F, Schnitzler JP. Daily variation of GDP synthase gene expression, DMADP and GDP levels in the leaves of the isoprene-emitting oak Quercus robur. GenBank Accession AM410990. 2006. Terpnet 2007, Strasbourg, France.

62. Stotz HU, Long SR. Expression of the pea (Pisum sativum L.) a-tubulin gene TubA1 is correlated with cell division activity Plant Molecular Biology Volume 1999; 41(5): 601-614. DOI: 10.1023/A:1006338401808

63. Kopczak SD, Haas NA, Hussey PJ, Silflow CD, Snustad DP. Small Genome of Arabidopsis Contains at Least Six Expressed a-Tubulin Genes The Plant Cell, Vol. 1992; 4: 539-547.

64. Oakley RV, Wang YS, Ramakrishna W, Harding SA, Tsai CJ. Differential Expansion and Expression of $\alpha$ - and $\beta$-Tubulin Gene Families in Populus. Plant Physiology November 2007; 145(3): 961-973.

65. Jacobs M, Rubery P. Naturally occurring auxin transport regulators. Science 1998; 241:346-349.

66. Peer WA, Murphy AS. Flavonoids and auxin transport: modulators or regulators? Trends in Plant Science 2007; 12(12): 556-563.

67. Chen Z, Gallie DR. Dehydroascorbate reductase affects leaf growth, development, and function. Plant Physiol. 2006; 142: 775-787.

68. Arrigoni O. Ascorbate system in plant development. Journal of Bioenergetics and Biomembranes1994; 26: 407-419.

69. Shaikhali J, Baier M. Ascorbate-dependent regulation of 2-Cys peroxiredoxinA promoter activity is light-dependent. J. Plant Physiol. 2010; 167:461-467.

70. Pasternak TP, Prinsen E, Ayaydin F, Miskolczi P, Potters G, Asard H, Vanonckelen HA, Dudits $D$, Fehér $A$. The role of auxin, $\mathrm{pH}$, and stress in the activation of embryogenic cell division in leaf protoplast-derived cells of alfalfa. Plant Physiology 2002; 129(4): 1807-1819.

71. Lerner HR, Avron M. Dihydroxyacetone Kinase Activity in Dunaliella parva. Plant Physiol. 1977; 59(1):15-17.

72. Abrahamian $P$, Kantharajah A. Effect of Vitamins on In Vitro Organogenesis of Plant American Journal of Plant Sciences 2011; 2: 669-674.

73. Schupp N, Ziegler $P$. The relation of starch phosphorylases to starch metabolism in wheat. Plant Cell Physiol 2000; 45: 1471-1484.

74. Eastmond PJ, Rawsthorne S. Coordinate changes in carbon partitioning and plastidial metabolism during the development of oilseed rape embryos. Plant Physiology 2000; 122: 767-774.

75. Dryt I, Smith A, Edwards A, Bhattacharyya M, Dunn' P, Martin C.

Characterization of cDNAs encoding two isoforms of granule-bound starch 
synthase which show differential expression in developing storage organs of pea and potato. The Plant Journal 1992; 2(2): 193-202.

76. Konradova H, Lipavska H, Albrechtova J, Vreugdenhil D. Sucrose metabolism during somatic and zygotic embryogenesisin Norway spruce: content of soluble saccharides and localization of key enzyme activities. Journal of Plant Physiology 2002; 159: 387-396.

77. Collada C, Caballero RG, Casado R, Aragoncillo C. Seed storage proteins in Fagaceae: similarity between Castanea globulins and Quercus glutelins, Plant Sci. 1991; 75: 145-154.

78. Sghaier-Hammamia B, Driraa N, Jorrín-Novo JV. 2009. Comparative 2-DE proteomic analysis of date palm (Phoenix dactylifera L.) somatic and zygotic embryos Journal of Proteomics Volume 73, Issue 1, 2 November 2009, Pages 161-177

79. Bertagnolli BL, Wedding RT.Purification and initial kinetic characterization of different forms of o-acetylserine sulfhydrylase from seedlings of two species of phaseolus. Plant Physiol. 1977; 60(1):115-21.

80. Minyaka E, Niemenak N, Issali EA, Sangare A, Denis NO. 2010.Sulphur depletion altered somatic embryogenesis in Theobroma cacao L. Biochemical difference related to sulphur metabolism between embryogenic and non embryogenic calli. African Journal of Biotechnology Vol. 9 (35), pp. 56655675 ,.

81. de Godoy LM, Olsen JV, Cox J, Nielsen ML, Hubner NC, Frohlich F, Walther TC, Mann M. Comprehensive mass-spectrometrybased proteome quantification of haploid versus diploid yeast. Nature 2008; 455: 1251-1254

82. Winkelmann T, Heintz D, Van Dorsselaer A, Serek M, Braun HP. Proteomic analyses of somatic and zygotic embryos of Cyclamen persicum Mill. reveal new insights into seed and germination physiology Planta Volume 2006; 224(3): 508-519, DOI: 10.1007/s00425-006-0238-8

83. Rode C, Lindhorst K; Braun HP; Winkelmann T. From callus to embryo: a proteomic view on the development and maturation of somatic embryos in Cyclamen persicum, Planta 2011; DOI 10.1007/s00425-011-1554-1

84. Giegé P, Heazlewood JL, Roessner-Tunali U, Millar AH, Fernie AR, Leaver CJ, Sweetlove LJ. Enzymes of Glycolysis Are Functionally Associated with the Mitochondrion in Arabidopsis Cells. The Plant Cell 2003; 15 (9): 21402151

85. Wurtele, E.S. and B.J. Nikolau. Differential Accumulation of Biotin Enzymes During Carrot Somatic Embryogenesis. Plant Physiology 1992; 99:1699-1703

86. Wallsgrove, R.M., Keys, A.J., Lea, P.J., and Miflin, B.J. Photosynthesis, photorespiration, and nitrogen metabolism.Plant Cell Environ. 1983; 6: 301309.

87. Gallardo, K., Job, C., Groot, S. P. C., Puype, M., Demol, H., Vandekerckhove, J. and Job, D. (Importance of methionine biosynthesis for Arabidopsis seed germination and seedling growth. Physiologia Plantarum 2002; 116: 238-247. doi: 10.1034/j.1399-3054.2002.1160214.x 
88. Ingram J, Bartels $D$. The molecular basis of dehydration tolerance in plants. Annu. Rev. Plant Physiol. Plant Mol. Biol. 1996; 47: 377-403.

89. Hosseini SS, Mashayekhi K, Alizadeh M. Ethylene production and somatic embryogenesis of carrot explants as affected by salicylic acid treatment. American-Eurasian J Agric \& Environ Sci 2009; 6 (5): 539-545

90. Hays DB, Yeung EC, Pharis RP. 2002. The role of gibberellins in embryo axis development J. Exp. Bot. 2002; 53 (375): 1747-1751. doi: 10.1093/jxb/erf017

91. Santanen A. Polyamine metabolism during development of somatic and zygotic embryos of Picea abies (Norway spruce). 2000; PhD dissertation. (Department of Biosciences, University of Helsinki).

92. Minocha SC, Minocha R. Role of polyamines in somatic embryogenesis. In: Bajaj, Yps, ed. Somatic embryogenesis and synthetic seed, 1995; Vol. 30. London, UK: Springer-Verlag Publishers: 53-70.

Table 1. Proteins identified on 2-DE maps from somatic embryos of $Q$. suber and function 


\section{Table 1 Q. suber Gomez-Garay et al..docx}

Click here to download Table: Table 1 Q. suber Gomez-Garay et al..docx

\begin{tabular}{|c|c|c|c|c|c|c|c|c|c|c|c|c|c|c|c|c|}
\hline \multirow[b]{2}{*}{$\begin{array}{l}\text { Spot } \\
\text { no. }\end{array}$} & \multirow[b]{2}{*}{ Protein definition from database } & \multirow{2}{*}{$\begin{array}{c}\text { Protein } \\
\text { definition by } \\
\text { BLAST query }\end{array}$} & \multirow[b]{2}{*}{ Accession } & \multirow[b]{2}{*}{$\begin{array}{c}\text { Mascot } \\
\text { Score }\end{array}$} & \multirow[b]{2}{*}{$\begin{array}{c}\text { Theoretical } \\
\text { MW }\end{array}$} & \multirow[b]{2}{*}{$\begin{array}{c}\text { Theoretical } \\
\text { pl }\end{array}$} & \multirow[b]{2}{*}{$\begin{array}{l}\text { Matched } \\
\text { peptides }\end{array}$} & \multirow[b]{2}{*}{$\begin{array}{c}\% \\
\text { Coverage }\end{array}$} & \multicolumn{2}{|c|}{ PSE vs CSE } & \multicolumn{2}{|c|}{ CSE vs MSE } & \multicolumn{2}{|c|}{ PSE vs MSE } & \multicolumn{2}{|c|}{$\begin{array}{c}\text { PSE vS } \\
\text { CSE+MSE }\end{array}$} \\
\hline & & & & & & & & & \begin{tabular}{|l} 
DIGE \\
Av. \\
Ratio \\
\end{tabular} & T-test & \begin{tabular}{|c|} 
DIGE \\
Av. \\
Ratio
\end{tabular} & T-test & $\begin{array}{c}\text { DIGE } \\
\text { Av. } \\
\text { Ratio }\end{array}$ & T-test & $\begin{array}{c}\text { DIGE } \\
\text { Av. } \\
\text { Ratio }\end{array}$ & T-test \\
\hline 1 & $\begin{array}{c}\text { manganese superoxide dismutase } \\
\text { [Digitalis lanata] }\end{array}$ & & gil9929159 & $\underline{105}$ & 24799 & 8,01 & $\underline{2}$ & $\underline{8}$ & 1,57 & 0,195 & 2,19 & 0,0381 & 3,43 & \begin{tabular}{|c|}
$2,32 \mathrm{E}-$ \\
03
\end{tabular} & 2,5 & 0,0256 \\
\hline 2 & $\begin{array}{c}\text { ascorbate peroxidase [Eucalyptus } \\
\text { camaldulensis] }\end{array}$ & & gil111434273 & $\underline{96}$ & 24968 & 5,36 & $\underline{3}$ & $\underline{22}$ & $-1,03$ & 0,588 & 2,05 & 0,146 & 2 & 0,0134 & 1,49 & 0,779 \\
\hline 3 & catalase [Populus deltoides] & & gi|90818816 & $\underline{103}$ & 57073 & 6,76 & $\underline{8}$ & $\underline{17}$ & 1,59 & \begin{tabular}{|c|}
$9,25 \mathrm{E}-$ \\
03
\end{tabular} & 1,3 & 0,0719 & 2,06 & $\begin{array}{c}1,11 \mathrm{E}- \\
03\end{array}$ & 1,83 & $\begin{array}{c}7,29 \mathrm{E}- \\
04\end{array}$ \\
\hline 5 & 2-cys peroxiredoxin [Vigna radiata] & & gil269980509 & $\underline{128}$ & 28690 & 5,5 & $\underline{2}$ & $\underline{11}$ & 2,01 & 0,154 & 1,46 & 0,33 & 2,94 & \begin{tabular}{|c|}
$2,62 \mathrm{E}-$ \\
03
\end{tabular} & 2,48 & 0,0233 \\
\hline 6 & $\begin{array}{l}\text { formate dehydrogenase [Populus } \\
\text { trichocarpa] }\end{array}$ & & gi|224129102 & $\underline{138}$ & 42533 & 6,61 & $\underline{3}$ & $\underline{12}$ & 2,12 & 0,454 & 1,51 & 0,253 & 3,19 & \begin{tabular}{|c|}
$3,71 \mathrm{E}-$ \\
03
\end{tabular} & 2,66 & 0,0948 \\
\hline 7 & $\begin{array}{l}\text { putative quinone reductase [Vitis } \\
\text { vinifera] }\end{array}$ & & gi|37724581 & $\underline{140}$ & 17612 & 5,59 & 1 & $\underline{9}$ & 1,52 & 0,698 & 1,77 & 0,258 & 2,68 & 0,0457 & 2,1 & 0,208 \\
\hline 8 & $\begin{array}{l}\text { proteasome subunit alpha type, } \\
\text { putative [Ricinus communis] }\end{array}$ & & gi|255583952 & $\underline{152}$ & 27504 & 5,84 & $\underline{5}$ & $\underline{25}$ & $-1,19$ & 0,313 & 1,54 & 0,0321 & 1,3 & 0,125 & 1,07 & 0,827 \\
\hline 9 & $\begin{array}{c}\text { heat-shock protein } 70 \text { [Dactylis } \\
\text { glomerata] }\end{array}$ & & gil188011548 & $\underline{182}$ & 72002 & 5,03 & $\underline{8}$ & $\underline{14}$ & 4,23 & 0,135 & $-1,49$ & 0,995 & 2,83 & 0,0175 & 3,53 & 0,0299 \\
\hline 11 & unnamed protein product [Vitis vinifera] & $\begin{array}{l}\text { Glutathione S- } \\
\text { transferase }\end{array}$ & gi|270247528 & $\underline{91}$ & 17441 & 6,19 & 1 & $\underline{7}$ & $-1,17$ & 0,835 & $-2,47$ & 0,0114 & $-2,9$ & 0,0331 & $-1,67$ & 0,172 \\
\hline 12 & $\begin{array}{c}\text { cinnamyl alcohol dehydrogenase } \\
\text { [Quercus ilex] }\end{array}$ & & gil82655175 & $\underline{130}$ & 36176 & 7,6 & $\underline{2}$ & $\underline{10}$ & $-1,23$ & 0,38 & $-1,22$ & 0,982 & $-1,5$ & $\begin{array}{c}5,03 \mathrm{E}- \\
04\end{array}$ & $-1,35$ & 0,194 \\
\hline 13 & $\begin{array}{c}\text { CR88; ATP binding [Arabidopsis } \\
\text { thaliana] }\end{array}$ & & gi|30678090 & $\underline{121}$ & 88658 & 4,93 & $\underline{8}$ & $\underline{10}$ & $-1,57$ & 0,0331 & $-1,13$ & 0,568 & $-1,78$ & 0,0151 & $-1,65$ & $\begin{array}{c}6,79 \mathrm{E}- \\
03\end{array}$ \\
\hline 14 & hypothetical protein [Vitis vinifera] & $\begin{array}{c}\text { ATP- } \\
\text { dependent } \\
\text { chloroplast } \\
\text { protease }\end{array}$ & gi|147866973 & $\underline{188}$ & 99169 & 6,09 & $\underline{12}$ & $\underline{16}$ & $-1,25$ & 0,109 & 1,51 & $\begin{array}{l}9,97 \mathrm{E}- \\
03\end{array}$ & 1,21 & 0,162 & 1 & 0,927 \\
\hline 15 & thaumatin-like protein [Citrus jambhir] & & gi|283131283 & $\underline{165}$ & 27551 & 8,18 & $\underline{2}$ & $\underline{9}$ & $-3,28$ & 0,0357 & $-1,03$ & 0,725 & $-3,38$ & \begin{tabular}{|c|}
$2,29 \mathrm{E}-$ \\
03
\end{tabular} & $-3,32$ & $\begin{array}{c}6,39 \mathrm{E}- \\
03\end{array}$ \\
\hline 16 & $\begin{array}{r}\text { EM_EST:FP032657; FP032657 Querc } \\
\text { EST, clone LGOAAB7YL15RM1, } \\
\text { OLP1_SOLLC Osmotin-like protein } \\
\text { - Solanum lycopersicum. }\end{array}$ & $\begin{array}{l}\text { us robur xylem } \\
\text { imilar to } \\
\text { precursor. }\end{array}$ & $\underline{\text { FP032657 }}$ & $\underline{253}$ & 19668 & 8,92 & $\underline{7}$ & $\underline{53}$ & $-1,97$ & \begin{tabular}{|l|}
$2,51 \mathrm{E}-$ \\
03
\end{tabular} & $-2,11$ & $\begin{array}{l}3,51 \mathrm{E}- \\
03\end{array}$ & $-1,07$ & 0,623 & $-2,04$ & $\begin{array}{l}2,40 \mathrm{E}- \\
04\end{array}$ \\
\hline 17 & auxin-induced protein PCNT115 & & gil728744 & $\underline{126}$ & 34292 & 7,1 & $\underline{5}$ & $\underline{17}$ & 1,03 & 0,679 & 1,66 & \begin{tabular}{|c|}
$4,00 \mathrm{E}-$ \\
03
\end{tabular} & 1,71 & 0,0356 & 1,37 & 0,128 \\
\hline 18 & hypothetical protein [Vitis vinifera] & RNA-binding & gil147828051 & $\underline{116}$ & 39230 & 6,24 & $\underline{2}$ & $\underline{6}$ & $-1,57$ & $3,91 \mathrm{E}-$ & 1,44 & 0,0373 & $-1,09$ & 0,251 & $-1,29$ & 0,0623 \\
\hline
\end{tabular}




\begin{tabular}{|c|c|c|c|c|c|c|c|c|c|c|c|c|c|c|c|c|}
\hline & & protein & & & & & & & & 03 & & & & & & \\
\hline 19 & $\begin{array}{c}\text { phosphate binding protein [Shewanella } \\
\text { frigidimarina NCIMB 400] }\end{array}$ & & gi|114563931 & $\underline{171}$ & 34834 & 8,78 & $\underline{4}$ & $\underline{14}$ & $-2,15$ & 0,0787 & $-1,19$ & 0,996 & $-2,56$ & \begin{tabular}{|c|}
$2,29 \mathrm{E}-$ \\
03
\end{tabular} & $-2,34$ & 0,0139 \\
\hline 20 & 14-3-3 protein [Rheum australe] & & gi|197312897 & $\underline{134}$ & 29446 & 4,71 & $\underline{4}$ & $\underline{19}$ & $-1,4$ & 0,175 & $-1,17$ & 0,836 & $-1,64$ & \begin{tabular}{|c|}
$7,00 \mathrm{E}-$ \\
04
\end{tabular} & $-1,51$ & 0,0389 \\
\hline 21 & 14-3-3 protein 7 & & gi|26454609 & $\underline{104}$ & 28910 & 4,96 & $\underline{3}$ & $\underline{15}$ & $-1,64$ & 0,0553 & $-1,22$ & 0,59 & -2 & \begin{tabular}{|c|}
$2,09 \mathrm{E}-$ \\
04
\end{tabular} & $-1,8$ & $\begin{array}{c}4,28 \mathrm{E}- \\
03\end{array}$ \\
\hline 22 & alpha-tubulin [Gossypium hirsutum] & & gil134035496 & $\underline{294}$ & 50268 & 4,89 & $\underline{19}$ & $\underline{46}$ & $-1,82$ & 0,194 & $-1,21$ & 0,836 & $-2,2$ & 0,016 & $-1,99$ & 0,0754 \\
\hline 23 & alpha-tubulin [Trifolium repens] & & gi|37789885 & $\underline{267}$ & 42754 & 6,14 & $\underline{13}$ & $\underline{34}$ & $-1,52$ & \begin{tabular}{|c|}
$1,04 \mathrm{E}-$ \\
03 \\
\end{tabular} & $-1,2$ & 0,0372 & $-1,82$ & \begin{tabular}{|c|}
$4,79 \mathrm{E}-$ \\
04
\end{tabular} & $-1,66$ & $\begin{array}{c}1,14 \mathrm{E}- \\
04\end{array}$ \\
\hline 24 & alpha-tubulin 4 [Gossypium hirsutum] & & gi|23452339 & $\underline{78}$ & 34412 & 5,36 & $\underline{2}$ & $\underline{9}$ & 1,94 & $\begin{array}{c}8,58 \mathrm{E}- \\
03\end{array}$ & $-1,7$ & 0,0433 & 1,14 & 0,598 & 1,54 & 0,113 \\
\hline 25 & $\begin{array}{c}\text { chalcone isomerase [Garcinia } \\
\text { mangostana] }\end{array}$ & & gi|222478417 & $\underline{120}$ & 23437 & 4,94 & $\underline{2}$ & $\underline{9}$ & 1,87 & 0,0121 & 1,2 & 0,038 & 2,25 & \begin{tabular}{|c|}
$4,26 \mathrm{E}-$ \\
03
\end{tabular} & 2,06 & $\begin{array}{c}3,64 \mathrm{E}- \\
04\end{array}$ \\
\hline 26 & $\begin{array}{c}\text { flavanone 3-hydroxylase [Camellia } \\
\text { sinensis] }\end{array}$ & & gi|49861114 & $\underline{139}$ & 41780 & 5,61 & $\underline{5}$ & $\underline{16}$ & 2,48 & 0,0724 & 1,33 & 0,556 & 3,3 & 0,0477 & 2,89 & 0,0138 \\
\hline 27 & $\begin{array}{c}\text { dehydroascorbate reductase [Solanum } \\
\text { tuberosum] }\end{array}$ & & gil98978769 & $\underline{116}$ & 15868 & 5,37 & $\underline{1}$ & $\underline{11}$ & 1,54 & 0,317 & 2,78 & 0,0272 & 4,27 & \begin{tabular}{|c|}
$2,57 \mathrm{E}-$ \\
04
\end{tabular} & 2,9 & 0,0436 \\
\hline 28 & $\begin{array}{c}\text { vacuolar H+-ATPase catalytic subunit } \\
\text { [Pyrus communis] }\end{array}$ & & gil60592630 & $\underline{166}$ & 69014 & 5,27 & $\underline{10}$ & $\underline{18}$ & $-1,31$ & 0,281 & 1,85 & 0,0707 & 1,41 & $\begin{array}{c}1,10 \mathrm{E}- \\
04\end{array}$ & 1,09 & 0,921 \\
\hline 29 & $\begin{array}{l}\text { dihydroxyacetone kinase, putative } \\
\text { [Ricinus communis] }\end{array}$ & & gi|255586153 & $\underline{121}$ & 61487 & 5,54 & $\underline{3}$ & $\underline{8}$ & $-1,74$ & 0,0207 & 1,16 & 0,457 & $-1,49$ & 0,0166 & $-1,61$ & $\begin{array}{c}7,57 \mathrm{E}- \\
03\end{array}$ \\
\hline 31 & $\begin{array}{l}\text { granule-bound starch synthase } \\
\text { [Solanum hirtum] }\end{array}$ & & gi|67037738 & $\underline{157}$ & 39869 & 5,87 & $\underline{5}$ & $\underline{18}$ & 2,08 & 0,0248 & 1,13 & 0,559 & 2,35 & \begin{tabular}{|c|}
$1,01 \mathrm{E}-$ \\
03
\end{tabular} & 2,22 & $\begin{array}{c}1,63 \mathrm{E}- \\
03\end{array}$ \\
\hline 32 & $\begin{array}{c}\text { granule-bound starch synthase [Lycium } \\
\text { pilifolium] }\end{array}$ & & gil74231456 & $\underline{235}$ & 42750 & 6,3 & $\underline{4}$ & $\underline{11}$ & 2,7 & 0,0391 & 1,17 & 0,507 & 3,15 & \begin{tabular}{|c|}
$6,28 \mathrm{E}-$ \\
03
\end{tabular} & 2,92 & $\begin{array}{c}2,60 \mathrm{E}- \\
03\end{array}$ \\
\hline 33 & legumin precursor [Quercus robur] & & gi|1465711 & $\underline{295}$ & 55941 & 5,86 & $\underline{5}$ & $\underline{12}$ & 58,65 & 0,0437 & $-2,62$ & 0,886 & 22,4 & 0,0207 & 40,52 & 0,0126 \\
\hline 34 & legumin [Quercus acutissima] & & gi|9971255 & $\underline{222}$ & 13521 & 5,43 & $\underline{4}$ & $\underline{43}$ & 41,57 & 0,0776 & $-2,41$ & 0,949 & 17,23 & 0,0277 & 29,4 & 0,0272 \\
\hline 35 & $\begin{array}{c}\text { cysteine synthase, putative [Ricinus } \\
\text { communis] }\end{array}$ & & gil255542380 & $\underline{126}$ & 34435 & 5,5 & $\underline{4}$ & $\underline{15}$ & 1,35 & 0,0839 & $-1,56$ & 0,0267 & $-1,15$ & 0,363 & 1,11 & 0,591 \\
\hline 36 & $\begin{array}{l}\text { hypothetical protein isoform } 2 \text { [Vitis } \\
\text { vinifera] }\end{array}$ & $\begin{array}{c}\text { Alpha- } \\
\text { glucosidase }\end{array}$ & gi|225423963 & $\underline{107}$ & 98554 & 5,75 & $\underline{3}$ & $\underline{3}$ & $-1,25$ & 0,0835 & $-1,36$ & 0,0354 & $-1,69$ & $\begin{array}{c}5,93 \mathrm{E}- \\
03 \\
\end{array}$ & $-1,44$ & 0,0153 \\
\hline 37 & $\begin{array}{c}\text { triosephosphate isomerase, putative } \\
\text { [Ricinus communis] }\end{array}$ & & gi|255584863 & $\underline{240}$ & 27655 & 5,89 & $\underline{5}$ & $\underline{14}$ & $-1,07$ & 0,641 & 1,54 & 0,143 & 1,43 & 0,0321 & 1,18 & 0,723 \\
\hline 38 & $\begin{array}{c}\text { serine hydroxymethyltransferase } \\
\text { [Gossypium hirsutum] }\end{array}$ & & gil211906466 & $\underline{162}$ & 52382 & 7,57 & $\underline{6}$ & $\underline{17}$ & $-1,06$ & 0,583 & 1,67 & 0,145 & 1,58 & 0,0468 & 1,26 & 0,79 \\
\hline 39 & $\begin{array}{l}\text { glyceraldehyde-3-phosphate } \\
\text { dehydrogenase [Oryza sativa] }\end{array}$ & & gil968996 & $\underline{121}$ & 36641 & 6,61 & $\underline{5}$ & $\underline{15}$ & 1,55 & 0,0168 & $-1,35$ & 0,307 & 1,15 & 0,854 & 1,35 & 0,296 \\
\hline 40 & $\begin{array}{l}\text { pyruvate decarboxylase [Prunus } \\
\text { armeniaca] }\end{array}$ & & gil167374781 & $\underline{176}$ & 66205 & 5,74 & $\underline{5}$ & $\underline{8}$ & $-1,25$ & 0,0835 & $-1,36$ & 0,0354 & $-1,69$ & \begin{tabular}{|c|}
$5,93 \mathrm{E}-$ \\
03
\end{tabular} & $-1,44$ & 0,0153 \\
\hline
\end{tabular}




\begin{tabular}{|c|c|c|c|c|c|c|c|c|c|c|c|c|c|c|c|c|}
\hline 41 & predicted protein [Populus trichocarpa] & $\begin{array}{c}\text { Alcohol } \\
\text { dehydrogenase }\end{array}$ & gi|224131144 & $\underline{211}$ & 41833 & 6,1 & 11 & $\underline{29}$ & $-2,11$ & 0,276 & $-2,6$ & 0,311 & $-5,48$ & 0,0338 & $-3,04$ & 0,0566 \\
\hline 42 & hypothetical protein [Vitis vinifera] & $\begin{array}{l}\text { Methionine } \\
\text { synthetase }\end{array}$ & gi|147821107 & $\underline{195}$ & 81927 & 6,19 & $\underline{5}$ & $\underline{9}$ & 1,53 & 0,0123 & 1,46 & 0,0146 & 2,23 & $\begin{array}{c}2,57 \mathrm{E}- \\
04\end{array}$ & 1,88 & $\begin{array}{c}1,32 \mathrm{E}- \\
03\end{array}$ \\
\hline 43 & Sal k 3 pollen allergen [Salsola kali] & & gi|225810599 & $\underline{180}$ & 83795 & 5,97 & $\underline{4}$ & $\underline{7}$ & 1,49 & 0,0168 & $-1,03$ & 0,899 & 1,44 & $\begin{array}{c}9,33 \mathrm{E}- \\
04\end{array}$ & 1,46 & $\begin{array}{c}1,00 \mathrm{E}- \\
03\end{array}$ \\
\hline 44 & $\begin{array}{l}\text { 5-methyltetrahydropteroyltriglut } \\
\text { homocysteine methyltransferase } \\
\text { [Ricinus communis] }\end{array}$ & $\begin{array}{l}\text { mate-- } \\
\text { putative }\end{array}$ & gi|255569484 & $\underline{183}$ & 84896 & 6,09 & $\underline{6}$ & $\underline{9}$ & 1,62 & 0,0382 & & 1,7 & 0,0746 & 2,76 & 0,0114 & $\begin{array}{c}8,20 \mathrm{E}- \\
03\end{array}$ \\
\hline
\end{tabular}




\section{Figure $1 Q$. suber Gomez-Garay et al..docx}

Click here to download Figure: Figure $1 \mathrm{Q}$. suber Gomez-Garay et al..docx

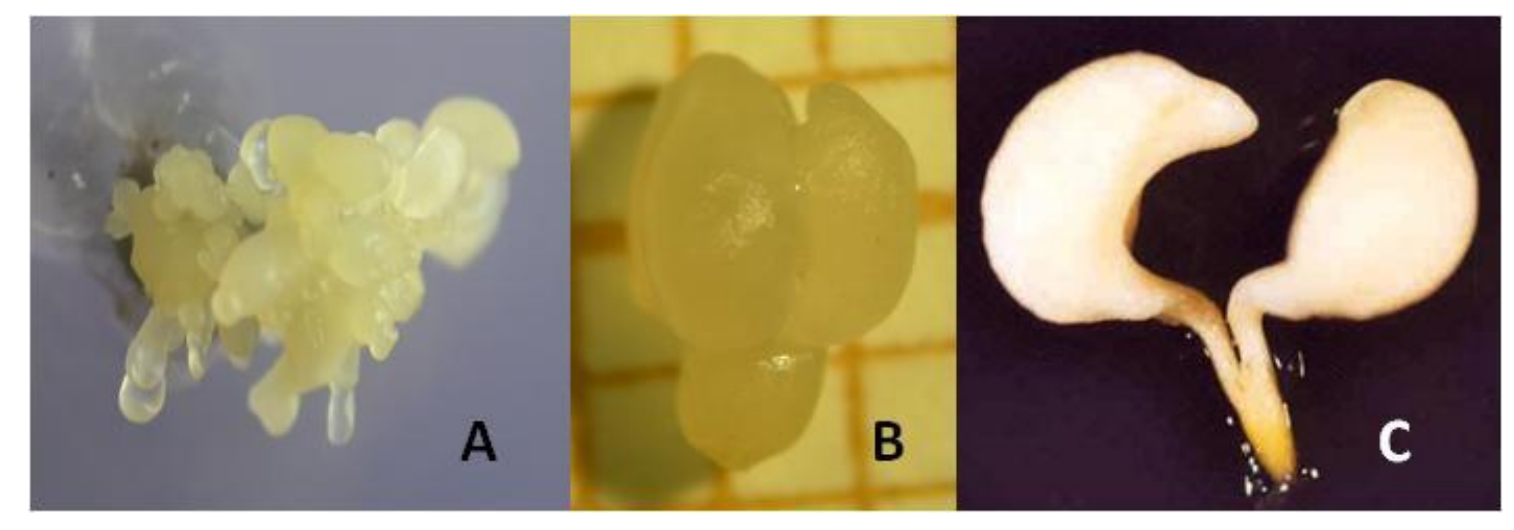




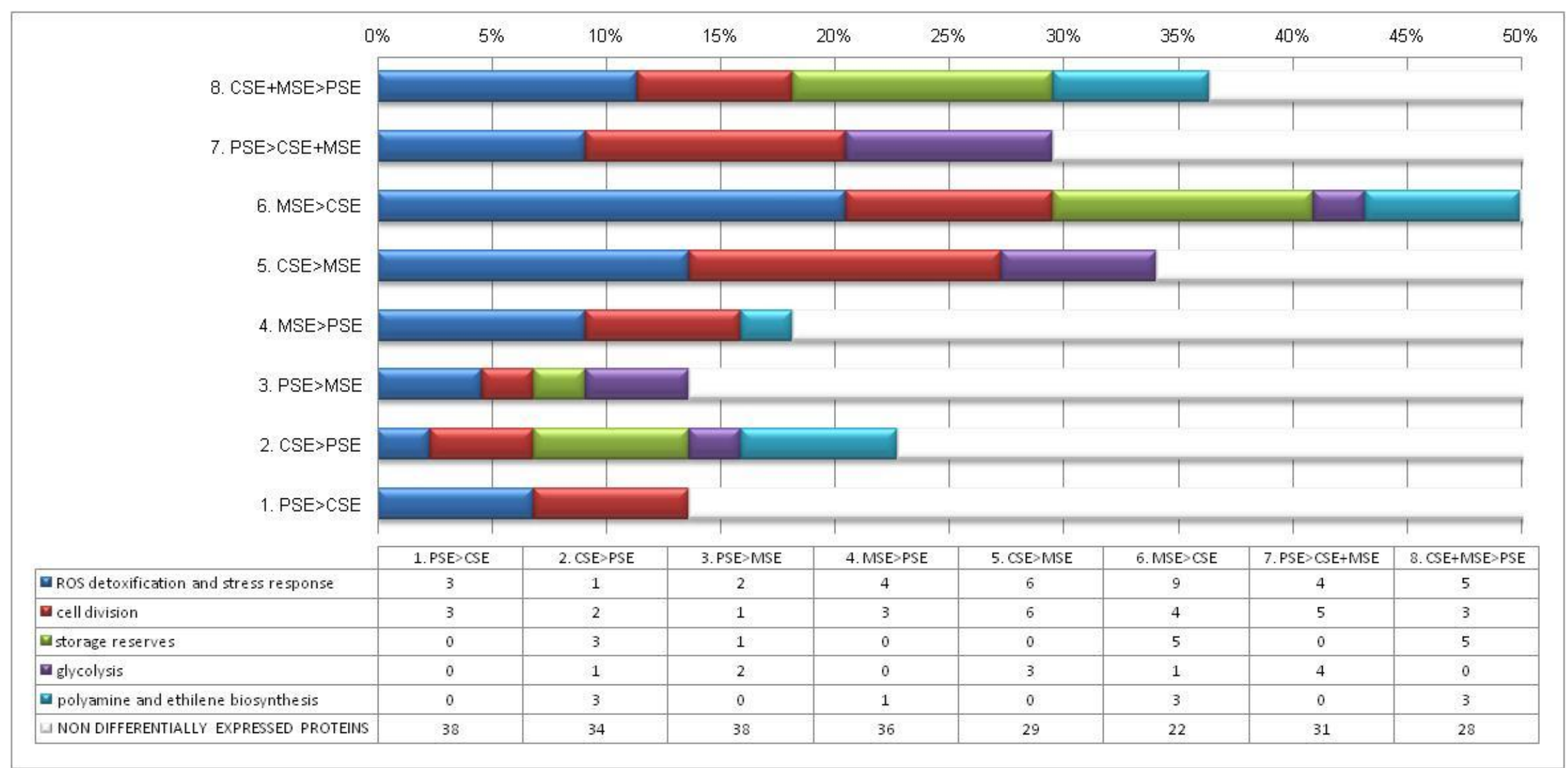


Figure 3 Q. suber Gomez-Garay et al..docx

Click here to download Figure: Figure 3 Q. suber Gomez-Garay et al..docx

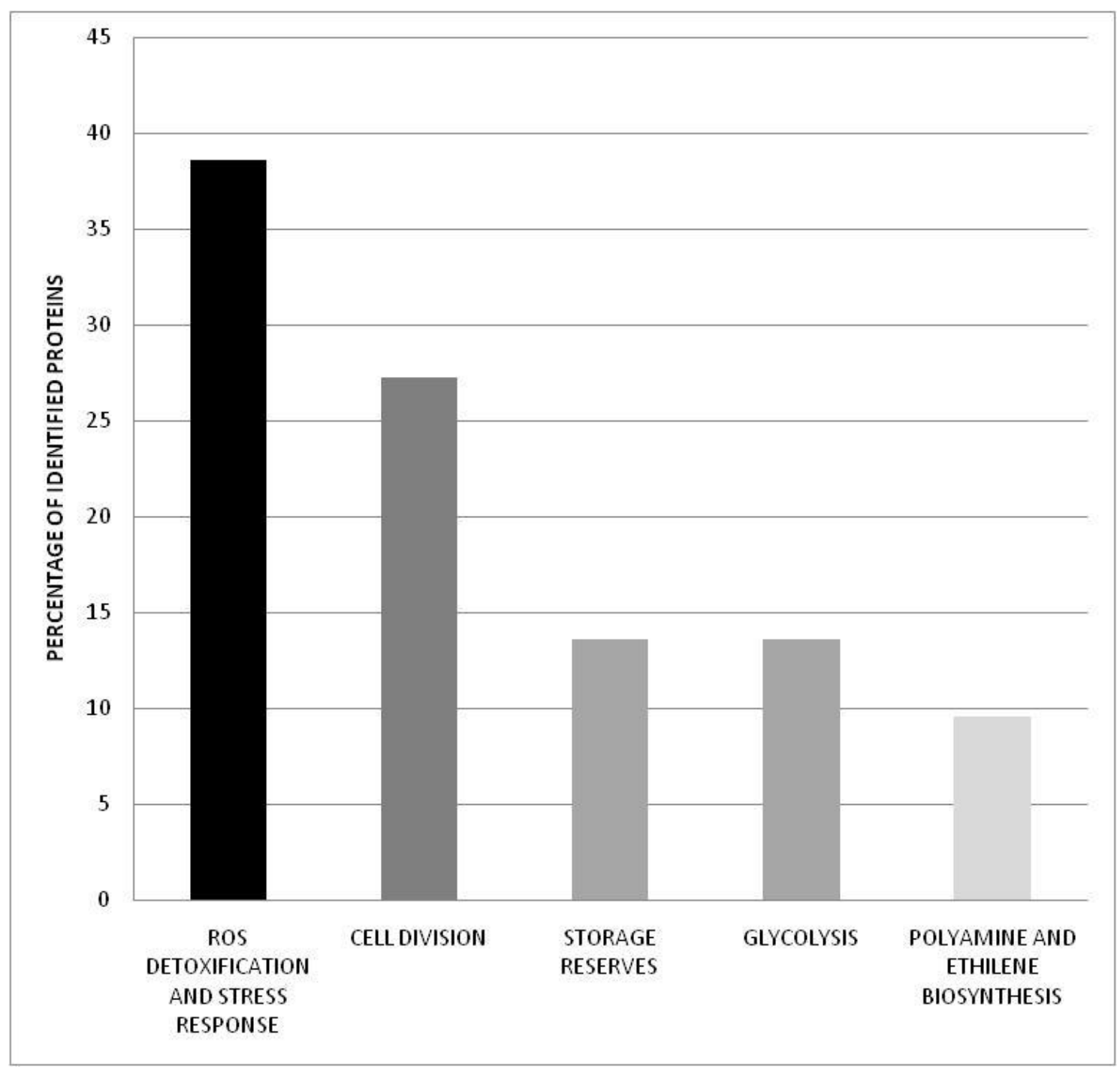




\section{FIGURE AND TABLE LEGENDS}

Figure 1. Q. suber somatic embryos at the three studied developmental stages. (A)

Proliferation stage (PSE). Embryos belonging to PSE are small embryos growing as a pool. (B) Cotyledonar stage (CSE). Embryos belonging to CSE are individual, well shaped embryos with white cotyledons. (C) Mature somatic embryo (MSE). Cotyledonar embryos turn into mature embryos (mature somatic embryos, MSE) and reach germination capacity.

Figure 2. Relative expression levels of proteins over $Q$. suber somatic embryo developmental stages. Type-1 and -2 members correspond to proteins found up- and down-regulated, respectively, between PSE and CSE. Type-3 and -4 proteins showed up- and down-regulated, respectively, between CSE and MSE, whereas type- 5 and -6 members were found up- and down-regulated, respectively, between PSE and MSE, and type-7 and -8 proteins revealed upand down-regulated, respectively, between proliferating and joined CSE and MSE embryos.

Figure 3. Classification of differentially regulated proteins during $Q$. suber somatic embryogenesis according to their functional annotations.

Table 1. List of the 44 differentially expressed proteins from $Q$. suber somatic embryos at three developmental stages (PSE, CSE and MSE). 